Sławomir Kamosiński

(Kazimierz Wielki University in Bydgoszcz, Bydgoszcz)

ORCID: 0000-0001-9314-4991

slawomirkamosinski@ukw.edu.pl

\title{
ENTREPRENEURS AND ENTREPRENEURSHIP IN THE EXPOSÉ OF THE PRIME MINISTERS: FROM TADEUSZ MAZOWIECKI TO MATEUSZ MORAWIECKI
}

\begin{abstract}
The Prime Minister's program speech, called the exposé, attracts particular attention. Its essence comes down to presenting the government's program. In a few key words, the Prime Minister often summarizes the framework proposals of his government in terms of economic policy, social policy, education, health care, the army as well as individual social and professional groups. The words spoken by the Prime Minister, asking for confidence in the government that has just been formed set the direction for the entire Council of Ministers for subsequent years. In this regard, there is a need to examine the economic policy of every Prime Minister in office since 1989 considering entrepreneurs. What offer did the heads of government make to entrepreneurs, what kind of support could this group count on, how were the institutions supporting the economy and political institutions evaluated? The aim of this article is to find answers to the presented problems.
\end{abstract}

Keywords: Prime Minister, Prime Minister's exposé, government's economic policy towards entrepreneurs, support for entrepreneurship

doi: 10.2478/sho-2020-0006

\section{INTRODUCTION}

The program speech of the President of the Council of Ministers, called the exposé, attracts particular attention. Its essence comes down to presenting the government's program. In a few key words, the Prime Minister often summarizes the framework proposals of his government in terms of economic policy, social policy, education, health care, and the 
military, individual social and professional groups. The words spoken by the Prime Minister, asking for confidence for the government that has just been formed set the direction for the entire council of ministers for the coming years. The literature also points out that the content and manner of delivering the program speech has a huge impact on creating the image of the newly formed government [Exposé Prezesów... 2020: 5].

Regardless of the political option represented by the Prime Minister, in every program speech, he referred to the fundamental value of trust. The President of the Council of Ministers asked to put trust in the newly formed government pointing out the need to rebuild confidence in national political and economic institutions, and called for the public to trust the direction of social and economic policy chosen by his government. He spoke of the need to strengthen the citizens' trust in one another. The politicians ruling the country know that, in Poland, there is a very high level of lack of trust in the everyday life of its citizens. Those in power realize that this situation increases government expenditure and the costs of running a business by enterpreneurs. This hinders mutual contacts between entrepreneurs, leads to an unwillingness of active citizens to deal with public matters, and contributes to the enslavement of political, social and economic life.

The lack of trust, this fundamental value, which is a building block that unites society, has been repeatedly pointed out by scholars, publicists and journalists who have studied this problem. The press, after 1989 contains many comments from specialists on this subject. In 2006, Professor Jacek Kurczewski said in "Tygodnik Powszechny", "Polish society is streaked with distrust..." [Kurczewski J. 2006: 3]. He wrote, "Distrust is a relatively coherent system of beliefs and should therefore be treated as a legitimizing action. However, what does it legitimize? Self! Because institutionalized mistrust delegitimizes and disrupts public life and refuses to legitimize the very center of politics" [Kurczewski J. 2006, 4]. Jacek Kurczewski was trying to find the sources of this state in Jacek Kuron's apt statement: "The classic situation (it is not from-the-hat situation) is Balcerowicz's leap of the initial period. At the time when we were going for elections in June 1989, I could not imagine at all what scope the so-called transformation would have i.e. change of order. (...) Hence, today one could ask whether it was not, politically speaking, a mistake. Were we right in assuming that it was necessary? So far, I don't see any other way out to create conditions for a market economy - when the central system broke down" [Kurczewski J. 2006: 4]. Considering this apt diagnosis, it is easier to understand, that 
each programme speech of the next president of the Council of Ministers refered to the political transformation initiated in 1989 and privatisation of state-owned enterprises, which was its direct consequence. The program speeches given from Tadeusz Mazowiecki to Mateusz Morawiecki contain, depending on the political option from which the Prime Minister came from, a different assessment of this process. Each of the government leaders protects those social groups that were most affected by the process of the change of ownership and were unable to find their place in the new reality. This is understandable. On the other hand, the Prime Ministers paid little attention in his expose to the group that is crucial for building a new economic system, namely, the entrepreneurs. Laconically, some of them mentioned the need to shape entrepreneurial attitudes in society.

In this context, it seems appropriate to examine what the president of the Council of Ministers had to offer the entrepreneurs. The government's interest in the entrepreneurial attitude of the citizens and the problems of entrepreneurs is information about the directions and shape of economic policy. When it is high on the part of those in power, then the entrepreneurs' level of the optimism increases, and this has an impact on the size of the undertaken investments, often directly related to innovations.

The analysis of the exposé of successive presidents of the council of ministers was carried out based on the source material - the program speeches customarily delivered in the Sejm (House of Assemby) in order for the president of the council of ministers to gain a vote of confidence for the newly built government. The excerpts from the speeches that appear in this text may give the text a reporting character. They are intended to illustrate the government's program and the announced economic policy regarding entrepreneurs.

\section{THE GOVERNMENT'S ECONOMIC POLICY PROGRAM AIMED AT ENTREPRENEURS IN THE PRIME MINISTERS' EXPOSÉ}

The year 1989 undoubtedly represents a breakthrough in both Polish and world history. The collapse of communism in Central and Eastern Europe radically changed the balance of political and economic power across the globe. The Cold War and the Bipolar World seemed to be only on the pages of history, and in 1989, Professor Francis Fukuyama 
asked in his essay, “The End of History? [Fukuyama F. 1989]. The hope of democratizing public life and building a free market in European countries that have so far been deprived of these institutions has turned out to be very much alive in these societies.

Tadeusz Mazowiecki formed the first non-communist government, in Poland. The Prime Minister, at the time of the so-called initial expose on August 24, 1989, was closely watched by the society, which, by giving him a huge credit of confidence, hoped to improve the quality of life of themselves himself and their children. The Prime Minister, already in the first sentence, announced pathetically: "I want to form a government capable of acting for the benefit of society, the nation and the state". To achieve this priority goal, he went on, "The current philosophy of the state must change. It cannot deal with everything and guarantee everything. It must facilitate and regulate activities. The most important role of the government and the administration at this time is to open up the possibilities for collective and individual actions [Mazowiecki T. 1989a]. The basic principle of the economic policy of the Council of Ministers led by Tadeusz Mazowiecki was expressed in these words. He expected that the new institutions, built in a country that found itself in a situation of transition from a totalitarian system with a centralized economy, to a democratic system with a free market economy, would activate the naturally occurring entrepreneurial resources in a society. The Prime Minister, by the means of announcing the radical economic reforms, wanted the Polish society to see the sense of self-employment. This was to be the guarantee for the country's economic success in the near future. For this reason, the Prime Minister emphasized the need, in Poland, to return to "known and proven economic institutions ". He explained that by this expression he meant restoring free market economy and related institutions in the country. He announced an institutional revolution. However, most of the society probably did not understand its essence. He stated: "My greatest desire is for the government of the current coalition to open up opportunities for Poles to raise the country's economy. We need such legal and economic mechanisms (in the guise of new institutions author's entry) that will give entrepreneurs a sense of security for their activities and allow everyone to find the moral and material sense of work" [Mazowiecki T. 1989a]. Speaking of the sense of security that the newly built institutions should provide to entrepreneurs, Tadeusz Mazowiecki probably had in mind the strengthening of the legal institutions to enable ownership of property and the guarantee of its inviolability. This is a key 
institution for any democratic state with a free market economy. It is a fundamental human right.

On September 12th 1989, Tadeusz Mazowiecki gave his exposé, which is considered to be the proper program speech of the Prime Minister. In the very first words of this speech, the Prime Minister emphasized that he will build a state in which citizens will live with dignity in a sovereign democratic country under the rule of law. Referring to an initial exposé in August 1989, he said that the goal of his administration was to support a healthy market economy that would motivate citizens to work honestly and perseveringly. He once again referred to the need to create economic institutions that will support structural changes in the economy. The Prime Minister emphasized that only with the persistent efforts of entrepreneurs can the country be successful on the European and global arena [Mazowiecki T. 1989b].

Tadeusz Mazowiecki, in his exposé delivered on September 12, 1989, vouched that his government would take the initiative to restore public confidence in the state. Being an experienced public servant and politician, he knew that any initiative taken by citizens in the economic and social arena must be based on this fundamental value. Poles, in the period of the People's Republic of Poland, which was no secret, did not trust the authorities of that time and treated them as foreign entities. During this historical period, the public's lack of trust in the political power and its institutions resulted from the negative assessment of the communist party in power. Tadeusz Mazowiecki intuitively felt that he had received a huge approval of trust following the electoral decision of the Poles and wanted to use that to build a state consisting of active citizens. Individual entrepreneurship was to be protected by the rule of law, and the legal framework was to remain the guarantor of individual freedom. The citizens had to be reminded of these basic principles at the outset of building a democratic state under the rule of law.

It should be noted that Tadeusz Mazowiecki used neither the term entrepreneur nor entrepreneurship in his exposé. It is difficult to speculate the reasons for this decision by the Prime Minister. After all, they were not concepts that could, in any way, irritate or divide society. On the contrary. Giving these words a special place in the two programme speeches of Tadeusz Mazowiecki's quoted above would certainly enhance the prestige and, thus, the role of entrepreneurs in the market economy system. The decision to omit these concepts in the exposé was probably dictated by political considerations. During the years of communist indoctrination, the 
Polish society had negative associations with the word "entrepreneur". The authorities of the People's Republic of Poland preserved the pejorative term in the public consciousness, as the so-called "privateers'. This approach led to the situation where the public trust in this professional group was undermined. Tadeusz Mazowiecki pointed out that "The changes in economic institutions, which the government intends to implement so quickly, will create favorable conditions for enterprising people, and thus, above all, for young people" [Mazowiecki T. 1989b].

The real economy at the end of 1989 and after 1990 experienced the socalled explosion of entrepreneurship. This phenomenon was on a global scale. More importantly, this was entrepreneurship based on the use of natural social resources. Due to this reason, many entrepreneurs who ran their business during those years of the People's Republic of Poland, after 1989, in order to stay on the market, immediately started to restructure their company, adapting it to the new operating conditions. The so-called 'old entrepreneurs' who had companies during those years of the People's Republic of Poland, along with a new group of entrepreneurs, who had established their businesses after 1989, often spontaneously, under impulse, all together allowing the Polish society to learn the spirit of capitalism. Morevoer, they unveiled the meanders of consumption in free market conditions, accelerated changes in the assortment of production, adjusting to current needs. It is important that these entrepreneurs gave the society a chance for a smoother transition, passing through the phase of, sometimes annoying, political transformation. With their daily work, this professional group proved that the process of changes taking place in the economy was irreversible. The private sector in 1990, outside of agriculture, had an $18 \%$ share in the generated national income and employed $12.1 \%$ of the total workforce (compared to $8.8 \%$ in 1989) [Rocznik Statystyczny 1991: XIV] ${ }^{1}$.

The government of Tadeusz Mazowiecki, enjoying the undisguised trust given on loan, undertook the effort to reform the state. The Parliament expanded the scope of freedom to conduct business activity in order to encourage citizens to choose the area of entrepreneurship. The institution of political power, building from scratch all the institutions of

\footnotetext{
${ }^{1}$ The statistical yearbook used the concept "former private sector". The rationale for using this category is as follows: "in order to ensure the comparability of data with previously published ones and to properly assess the privatisation phenomenon". The former private sector in total, i.e., including agricultural and non-agricultural activities, employed $33.3 \%$ of workers in 1989 and $38.9 \%$ in 1990.
} 
public life, wanted to involve the society in effective economic activity. Daron Acemoglu and James A. Robinson compared the role of inclusive economic institutions to the situation observed on the sports arena "with the same rules of the game for all" [Acemoglu D., Robinson J.A. 2014: 94]. This was the primary goal of the institutional reconstruction initiated in Poland after 1989 [Morawski W. 1998].

Jan Krzysztof Bielecki, the Prime Minister who took over from Tadeusz Mazowiecki, gave an exposé on 5 January 1991. The Prime Minister presented the programme speech of his government in a specific political atmosphere. Tadeusz Mazowiecki stepped down after losing in the first round of the election for the office of President of the Republic of Poland to Lech Wałęsa, and to an 'unknown' candidate - Stanisław Tymiński. This was a signal to the incumbent Prime Minister that he needed to resign his position. Tadeusz Mazowiecki resigned, justifying it with the public's distrust of the politics he had proposed. If one assumes that in the Prime Minister's exposé, the order of issues raised is of any importance, then Jan Krzysztof Bielecki, in the first part of his speech, addressed the entrepreneurial people rather indirectly, instead of directly. He said, "The task of the new government is to awaken individual ambitions and national aspirations, to give a new dynamic to the reforms. We will place importance on entrepreneurship and productivity" [Bielecki J.K. 1991]. He emphasized that the fundamental goal set for the country remained unchanged, which is to build a market economy in Poland. He announced that his administration would oppose the observed attitudes of doubt and apathy. Certainly, this worrying state of social mood was a result of the election campaign. Addressing entrepreneurs directly, the Prime Minister said, "Entrepreneurs must have attractive investment opportunities". Jan Krzysztof Bielecki explained that he had in mind the creation of "special entrepreneurship zones" in order to launch large entrepreneurial resources of the Polish society, which, in his opinion, had so far not been used [Bielecki J.K. 1991]. The Prime Minister made no other promises to this professional group. Instead, he paid more attention to discussing the process of change of ownership that was taking place in the Polish economy. Jan Krzysztof Bielecki spoke about the social effects of reforms and emphasized the need to implement effective social policy programs in order to protect the citizens from the unexpected consequences of the new free market economic policy. Such a laying of emphasis in the exposé justifies the Prime Minister. His goal was to calm down social emotions that was the result of citizens' observation of the first fully democratic 
election campaign. The promises made by the candidates for the office of President of the Republic of Poland, relating to the settlement of dishonest entrepreneurs and "taking them to the cleaners" undermined public trust in entrepreneurs and consequently discouraged many from making investments. Such actions of politicians were irresponsible and reckless in the emerging democracy.

The first fully democratic elections to the Sejm and Senate in Poland were held on October 27, 1991. Following the decision of the voters, the portfolio of the Prime Minister was entrusted to Jan Olszewski. The Prime Minister gave an exposé on December 21, 1991. Jan Olszewski, representing the coalition government of the parties Porozumienie Centrum, Zjednoczenie Chrześcijańsko-Narodowe, Polskie Stronnictwo Ludowe - Porozumienie Ludowe, Partia Chcijańskich Demokratów, devoted a great part of his speech to justify the need to overcome the state of paralysis in which, in his opinion, it had found itself. The Prime Minister said that this was the result of "inertia" on the part of the administration and the inability to perform basic tasks [Olszewski J. 1991]. He pointed to the deepening collapse of the Polish economy. He pointed out that, according to experts, "Poland has not yet even chosen a specific way to rebuild its economy, and the actions taken so far have lacked a uniform strategy" [Olszewski J. 1991]. The Prime Minister did not deny the basic direction of Poland's political and economic transformation, which was to strengthen the market economy. He did, however, specify this goal in the following words: "We want a market economy that operates within a strict legal framework and in which the Christian values of the family and other human communities are also protected. We want to use the experience of the great European democracies rebuilding countries after the Second World War in this endeavour" [Olszewski J. 1991].

In this program speech, Jan Olszewski presented the citizens with a tenpoint program aimed at overcoming, in his opinion, a deepening recession. He announced, "To organize property relations in the management of national property", to restore the institution of the state treasury, which will manage the state's property, "to equalise various forms of individual and collective property in economic activity". In order to achieve this goal, he declared a "balancing of the tax burden on public and private enterprises (...)". The Prime Minister pointed to the need for the government to support some of the state enterprises that have "demonstrated their competitive ability". He promised to stimulate exports, to introduce management contracts "concluded between enterprise management and 
state treasury agencies," to reduce budgetary expenditures by "improving the administration of the budgetary sphere and, at the same time, to increase revenues in the state" [Olszewski J. 1991]. The implementation of this postulate was connected, as Jan Olszewski pointed out, with the accession "to radical improvement of the state apparatus responsible for the inflow of this income" [Olszewski J. 1991]. The strengthening of the fiscal apparatus was connected directly with the announcement of improving tax collection from entrepreneurs. Since nobody likes paying taxes, this information was probably not enthusiastically received. Moreover, he announced the modernization and privatization of the banking system as well as pointing to the need to rebuild economic relations with countries that emerged following the collapse of the Soviet Union.

In his exposé, Jan Olszewski devoted a lot of thought to the evaluation of the privatisation process. In his opinion, "Privatization processes must be clearly structured and subject to effective control so as to limit abuse and looting of state property" [Olszewski J. 1991]. This was a direct message the authorities sent to people dissatisfied with the process of change of ownership that was taking place in the Polish economy. It had the character of a political manifesto addressed to a wide range of voters - people lost in the new economic and social reality. The Prime Minister saw the need to reprivatize property, announcing the submission of an appropriate bill. Speaking of clarifying and controlling changes of property in the economy that have been taking place since 1989, Jan Olszewski has questioned their fairness to date. It was a statement, which certainly contributed to the weakening of social trust towards the activity of political and economic institutions in Poland. This is similar to the information that the Prime Minister will strengthen the institutions of control over entrepreneurs. Such statements often built a negative image of entrepreneur in the social consciousness. Despite these unfavorable announcements for entrepreneurs, Jan Olszewski asked for the development of new entrepreneurship to be a leaven that creates good conditions for the development of small towns in the province, far away from large urban centers [Olszewski J. 1991].

Political turbulence made Hanna Suchocka to deliver her program speech on July 10,1992, during the 20th session of the Sejm in its first term of office. She asked for a vote of confidence in the new coalition government representing the following parties: Zjednoczenie Chrześcijańsko-Narodowe, Unia Demokratyczna, Kongres liberalno-Demokratyczny, Stronnictwo Ludowo-Chrześcijańskie, Polskie Stronnictwo Ludowe - Porozumienie 
Ludowe, Partia Chrześcijańskich Demokratów, Polska Partia Przyjaciół Piwa (i.e. Christian National Union, Democratic Union, Liberal Democratic Congress, People's Christian Party, Polish People's Party - People's Agreement, Party of Christian Democrats, Polish Beer-Lovers' Party). Prime Minister Hanna Suchocka confirmed that "the principle of shaping the economic system remains the social market economy proclaimed in this House by the first non-communist prime minister. This means a harmonious balance between individual responsibility for the existence of a person's family and social solidarity" [Suchocka H. 1992a]. In the project of economic policy, Hanna Suchocka announced the reduction of the economic activity of the state ("reduction of the area of own economic activity") and the focus of the administration on the development of effective institutions supporting the free market [Suchocka H. 1992a]. The principle of 'minimum state in the economy' was, invariably, adopted in the economic policy. The Prime Minister, announcing support for the development of the economy with the help of state institutions, promised to increase responsibility for the construction of economic infrastructure, including roads and railroads. The quality of communication routes was not adjusted to the growing needs of the market economy. The shortage of infrastructure slowed down economic growth, which became a brake on development.

Hanna Suchocka declared that the administration would respect private property and the right to freedom of contract. This is the foundation of entrepreneurship, she said. She announced an effort to build a stable legal system, which is a condition for a smooth functioning of the free market. Hanna Suchocka set a goal, for the Council of Ministers, of putting the state finances in order: "We expect that the Sejm will soon pass the bill on the value added tax. (...) A clear tax system and a simplified way of paying taxes will bring everyone closer to the obvious truth that the government can only spend as much money as it collects from citizens [Suchocka H. 1992a]. At the same time, the Prime Minister emphasized reassuring entrepreneurs that increasing the tax burden was not the goal of the economic policy of her Government. She explained that high tax rates adversely affect the motivation of entrepreneurs to embark on investments and new economic initiatives. Recession cannot be allowed through irresponsible tax policy. For the first time, the Prime Minister noted this problem in an exposé and named it.

Prime Minister Hanna Suchocka, on the floor of the Sejm, gave the so-called second exposé on October 9, 1992. It should be noted that not 
all heads of government decided to take such a step. Often, the second exposé specifies the conversation threads of the first program speech, and new projects, previously omitted, were also added. In this program speech, Hanna Suchocka pointed out that "We need a clear perspective on the future as well as the awareness that our efforts are not in vain" [Suchocka H. 1992b]. In this way, the Prime Minister wanted to arouse social enthusiasm, strengthen social hope and, by overcoming doubts, rebuild public confidence in political institutions. She announced that her government intended to launch processes of development and economic growth to speed up the country's recovery from the recession caused by the transformation.

Hanna Suchocka outlined the economic policy program of her Government in seven points. In her first point, she drew attention to the fundamental principles of institutional order, including the security of citizens, the sense of stable management, respect for property, respect for workers' rights and the citizens' respect for state authorities and offices. Furthermore, in the seven-point program, the Prime Minister expected, in response to an economic policy tailored to the needs of entrepreneurs, a greater involvement of local entrepreneurs in investment activities. In her opinion, they are a permanent factor for economic growth, hence the appeal for more of them. The Prime Minister made an attempt to knock society out of apathy by saying: "There are no victories without the will to win, there are no successes without belief in success" [Suchocka H. 1992b].

Hanna Suchocka, in her second exposé, did not criticize the change of ownership in Poland after 1989 and did not question its meaning. She stressed the importance of her activities for building sustainable economic growth. She asked to "preserve the positive achievements of the reforms". By these words, she distanced herself from the opinion expressed by her predecessor. She showed that: "By mid-1992, the private sector was already producing more than a third of the total domestic product, including $27 \%$ of industrial production, $75 \%$ of construction services, 31\% of transport" [Suchocka H. 1992b]. Praising the achievements of past years, she said: "More than half of the working population works in the private sector or makes a living from self-employment. Private entrepreneurs proved to be resistant to recession. The private sector in most areas of the economy increased production and employment by nearly 600 thousand people in 1991" [Suchocka H. 1992b]. The Prime Minister admitted with conviction that the persevering work of domestic entrepreneurs allowed to reduce 
unemployment and limit the adverse effects of the transformational recession. Addressing entrepreneurs, she emphasized that the private sector in the economy is one of the few that has never received "more serious assistance or government preferences." [Suchocka H. 1992b]. According to Hanna Suchocka, private companies "owe their creation to the initiative, entrepreneurship and work of people who have chosen a risky, but independent and effective path. However, they usually have little capital. These are usually small family businesses" [Suchocka H. 1992b]. In this way, none of the Prime Ministers spoke about the entrepreneurs and their work in their exposé. From the parliamentary rostrum, Hanna Suchocka pointed to entrepreneurs as the main directors of economic growth. She spoke with appreciation about their work, emphasizing the fact that Poles are not afraid of risks involved with taking up business [Suchocka $\mathrm{H}$. 1992b]. The Prime Minister's attention to the work of entrepreneurs was a clear signal of support sent to them from the parliamentary rostrum. However, the promises made to entrepreneurs were not implemented due to another change of government.

On September 19, 1993, after the shortening of the first parliamentary tenure, new elections were held. As a result, Waldemar Pawlak was entrusted with the mission of forming a new government. The Prime Minister built a government consisting of the Polish People's Party and the Social Democracy of the Republic of Poland. He presented the required exposé in the Parliament on November 8, 1993. In his speech, Waldemar Pawlak repeatedly referred to the economic situation of state-owned enterprises, and raised the issue of their restructuring, privatization and bankruptcy. He considered unemployment to be a fundamental social problem that led to the spread of poverty and misery in Poland. He criticized the functioning of many institutions that affect the economy, including the paresis of the justice system. He spoke about the difficult situation of education, health care and culture. He announced, and this element has remained unchanged in the Prime Ministers' exposé since 1989, that reforms aimed at strengthening free market mechanisms and democracy would continue. He spoke with conviction: "After all, the idea of economic freedom has brought about a balanced market, a realistic cost and a wide range of human enterprise" [Pawlak W. 1993].

Waldemar Pawlak, importantly, did not overlook the so-called small business. In his opinion, it revives the economy, protects it from recession and contributes to building sustainable economic growth. He declared that small enterprises deserve state aid. Special economic zones were to be 
created in areas with evident economic collapse as a form of tangible help. He also announced "the creation of conditions for the effective operation of all economic entities in the market economy being built" [Pawlak W. 1993].

Waldemar Pawlak's words about the need to modify the tax system "so that the tax burden is distributed more fairly than before" were addressed, indirectly, to entrepreneurs. Although, not everyone will accept this proposal with enthusiasm, however, his government unlike the previous ones considers the protection of the poorest and social solidarity an important principle of its actions" [Pawlak W.1993]. Waldemar Pawlak also addressed the entrepreneurs directly, saying: "In the search for solutions that would allow us to boost the development of our economy, we count on practical knowledge and cooperation of the Polish entrepreneurs. We will make every effort to ensure that their initiatives, which have already been submitted and those that are yet to emerge can be implemented efficiently" [Pawlak W. 1993].

Waldemar Pawlak encouraged businessmen to cooperate with the institution of political power. He declared a substantive dialogue with the professional group that is the guarantor of economic growth. This was a new element, in light of the speeches made by the heads of government so far. The institution of political power opened up to dialogue with entrepreneurs, signaling the need to build inclusive political and economic institutions. This is probably how the intention of the Prime Minister can be read - a good forecast for the future. Waldemar Pawlak tried to break the barrier of mistrust between the government and entrepreneurs.

In the exposé under consideration, Prime Minister Waldemar Pawlak touched upon a theme that has invariably appeared in all of the program speeches of the heads of government - the institution of property rights. He declared that "The market economy requires the respect and guarantee of property rights." This assurance was to be one of the elements that were to restore the trust of the citizens in the institution of political power, including entrepreneurs. In order to confirm the credibility of the words spoken, the Prime Minister pointed out the problems with the final preparation of the bill on re-privatization. In his opinion, this act of law "will be a compensation for the harm done and will confirm the durability of property rights" [Pawlak W. 1993].

To sum up, Waldemar Pawlak devoted a lot of attention in his exposé of November 8, 1993 to discussing social policy programs, including programs intended to help people affected by market reforms that were 
initiated in Poland after 1989. There was also a new socially beneficial theme of privatization of state-owned enterprises and the place of stateowned enterprises in the national economy. However, there was no broad offer for the future, for people open to change, all those who wanted to get rich and dynamically change the reality.

The lack of trust of the center of political power in entrepreneurs and entrepreneurs in them likewise was too much to be so quickly eliminated. This was a fundamental shortcoming of the economic policy pursued by successive governments after 1989. The prime ministers paid a lot of attention in their exposé to the analysis of change of ownership, omitting the problems of entrepreneurs. Usually the offer for this professional group included the reform and empowerment of tax services, change of tax laws and increase of tax controls. Such rhetoric built a wall of indifference between the center of political power and entrepreneurs.

Józef Oleksy presented the program objectives of his government, which was built on the foundation of a coalition of the Polish People's Party and the Social Democracy of the Republic of Poland to the Parliament, on March 3, 1995. In terms of the government's economic policy directly affecting entrepreneurs and support for entrepreneurial initiatives, the Prime Minister had little to offer. He mentioned with appreciation that one of the groups, because of which Poland is recovering from the economic crisis, were those who took "the financial and life risks that accompany running a business, thanks to those who work hard and patiently endure sacrifice in the name of the common good" [Oleksy J. 1995]. It is difficult to explain why Józef Oleksy did not call on those who had taken risks in running their business directly as entrepreneurs. He simply avoided this notion. It is not clear what the reasons were behind this decision. The direct term 'entrepreneur' appears in Józef Oleksy's exposé in the following context: "Entrepreneurs rightly expect the transparency and sustainability of the tax system, the availability of the cheapest possible credit, and the security of their money deposited in banks" [Oleksy J. 1995]. In this single sentence, the Prime Minister highlighted all the drawbacks that Polish entrepreneurs faced on a daily basis. However, he did not provide any remedy to change the situation. It can be stated that as is customary and in line with the tradition of the previous program speeches of the heads of government, Józef Oleksy announced the need to introduce changes in the tax system in order to ensure its sustainability and not to surprise entrepreneurs with more tributes and taxes. Cheap loans are the Prime Minister's assurance of support for investments to be 
undertaken by entrepreneurs. The words "Equal opportunities will be created for all business people" [Oleksy J. 1995], were simply to calm them down. This promise contained announcements of a public procurement system, regulations on conflicts of interest in politics and the economy as well as a firm counteraction of monopolistic practices in the economy. Józef Oleksy probably wanted to gain support for the economic policy of the government from groups representing state-owned enterprises and, in the face of the fragility of Polish financial capital, he intended to gain the favor of foreign investors.

Włodzimierz Cimoszewicz, after the political turbulence that appeared around the person of Józef Oleksy, received a mission to form a new government in January/February 1996. The Prime Minister, who built the government based on an ongoing coalition of the Polish People's Party and the Social Democracy of the Republic of Poland, gave a speech in the Parliament on February 14, 1996. In his exposé, he referred to the institutional weakness that has becomePolish experience. Hedrew attention to the sharp political dispute that was washing away the authority of the institution of political power. It destroyed public confidence in political power and, more broadly, in the state institutions [Cimoszewicz W. 1996]. This diagnosis of the Prime Minister was true. Deteriorating social sentiment, due to the crisis within political institutions, was not conducive for using the entrepreneurial resources of society and thus weakened the willingness of entrepreneurs to invest.

Włodzimierz Cimoszewicz, addressing the entrepreneurs, spoke flatteringly about their everyday work. He stressed their great influence on changing the structure of the Polish economy and pointed to their role as taxpayers in building the state budget. The Prime Minister said: "The better situation of Polish enterprises has been combined with an increasing share of revenues generated in the private sector, which is a measure of progressing ownership changes" [Cimoszewicz W. 1996]. The Prime Minister repeated, after Józef Oleksy, in the context of the rules of conducting business activity, that: "The government is aware that favourable rules and security of doing business as well as the limitation of fiscalism are the prerequisite for maintaining positive trends in the economy. This applies equally to large enterprises as well as to individual self-employed people." [CimoszewiczW.1996]. The Prime Minister, likehis predecessor, declared that his will was to create fair rules of doing business for all entities present on the market. He made a promise to "guarantee the security of economic transactions more fully, including changes in the 
bankruptcy law and the court business register" [Cimoszewicz W. 1996]. He mentioned the need to strengthen the independence of the judiciary and streamline its activities, because, as he said, it is an indispensable institution for the proper functioning of the state and economy.

Those who governed after 1989 saw the problem of lengthy court business proceedings, which, rather than resolve, slowed down economic growth and discouraged young entrepreneurs from starting up businesses. Apart from pointing to the weakness of the justice system, practically no action was taken to improve the economic justice.

The Parliament of the third term was elected through the elections held on September 21, 1997. Jerzy Buzek was entrusted with the mission of forming a new government. He headed the center-right coalition government of the Akcja Wyborcza Solidarność and Unia Wolności (Electoral Action Solidarity and Union of Liberty). The Prime Minister gave an exposé on November 10, 1997. Jerzy Buzek declared: "The right to private property must be widespread. The Polish middle class must be strengthened. We will not allow the economic rule of a narrow oligarchy to be formed in the Republic. We want a free economy with opportunities for all, we want a social dialogue between labour and capital." [Buzek J. 1997]. The desire to strengthen the middle class resounded clearly from the parliamentary rostrum for the first time since 1989. The middle class is the group that underpins economic growth, builds economic strength, and revitalizes large cities, small towns and villages alike. It is the fastest and most efficient group in dealing with economic turmoil. In his offer addressed to small and medium-sized entrepreneurs, artisans and merchants, Jerzy Buzek announced that his government would ensure easy access to loans. Once again, in the Prime Minister's parliamentary exposé, the problem of low inclination of native entrepreneurs to making bold investments, often connected with innovations, returned. They guarantee constant economic growth and, it should be emphasized, are the barometer of entrepreneurs' moods and faith in the future [Buzek J. 1997]. In the face of the leanness of domestic capital, bank loan became an instrument for many entrepreneurs to support their ideas, which they turned into investments. Entrepreneurs, as the practice of economic life showed, were afraid to use this instrument.

In the further part of his exposé, Prime Minister Józef Buzek discussed a broad vision of rebuilding the political institution of power, which in his opinion should effectively serve the citizens after the planned change. Referring to the project of a comprehensive state reform, he presented his 
vision: "Local government reform and the accompanying repair of public finances, privatization, reprivatization and popularization of property will create a foundation for effective implementation of the reform of the education system, health care, social welfare and pension system. Changes in the state structures and institutions with the society will allow for the building of an efficient economy, based on private property, an economy without monopolies, structurally modern, promoting the activity of citizens, as well as supporting the weakest who are unable to cope on their own" [Buzek J. 1997]. The reconstruction of the state's administrative center presented by the Prime Minister boiled down to speeding up of the decentralization of the executive power and, and as a result of this, more tasks are assigned to the local government.

The pain of social life, which plagued all spheres of life in Poland, was the corrosion of trust. The Prime Minister, like his predecessors, referred to this issue. Jerzy Buzek said, "Without the preservation of universally accepted moral values, there will be no efficient economy. After all, common work requires at least a minimum of trust between partners and a recognition of the value of human labour. The massive violation of social norms raises, as economists say, the costs of the economy" [Buzek J. 1997]. For the first time since 1989, the Prime Minister, in his exposé, so clearly stressed the problem of the relationship between moral principles, including trust, and economic growth as well as the costs of doing business.

Professor Wacław Wilczyński, an economist and commentator on economic matters in Poland, made a bitter remark in one of his columns in April 2001: "The worst thing is that our political establishment still does not understand that in order to have a healthy macroeconomy; there must be a healthy microeconomy, i.e. profitable, efficient, investment, and not stifling private enterprises" [Wilczyński W. 2001]. The Professor justified this opinion by the fact that after 1989 no open dialogue occurred between the government and Polish entrepreneurs. In its place was a mutual suspicion. He criticized the astonishing ability and, at the same time, the ease with which politicians and journalists built up an atmosphere of entanglement economic scandals around businessmen and thereby creating a huge amount of distrust in this professional group. Wacław Wilczyński accused the politicians that in 2001, the Polish economic policy was marked by "ubiquitous costly tenure'ism, centralism and tilltomorrow'ism in public finances" [Wilczyński W. 2001]. As a result, the state as an institution still did not trust entrepreneurs. The institutions that were responsible for providing public services, including the judicial 
system, failed. Subsequently, due to a deepening institutional crisis and a widespread lack of trust, the social potential and resources of entrepreneurship were inefficiently utilised in Poland. This bitter reflection summed up the decade of reforms.

The fourth parliamentary election was held on September 23rd 2001. Leszek Miller became the Prime Minister. He headed the centre-left coalition government of the Democratic Left Alliance, the Polish People's Party and the Labour Union. The Prime Minister delivered the Parliametary expose on October 25, 2001. Therein he diagnosed that despite the fact that many years have passed since the beginning of the transformation of the political and economic system, a deficit of trust in the state and local government institutions is still observed in Poland. This also concerns mutual relations between people. As a result of this fact, the citizens' po tential is very poorly utilized [Miller L. 2001].

Addressing entrepreneurs and people ready to start a business directly, Leszek Miller placed an offer in the form of a legislative package called "entrepreneurship first and foremost" [Miller L. 2001]. According to the Prime Minister's announcement, the document was to be a set of regulations that would make it easier for citizens to set up and run small and mediumsized enterprises. The second offer, addressed to entrepreneurs, as in the exposé of Leszek Miller's predecessors, was related to the revision of the tax law. The removal of inaccuracies and a number of gaps from this section of the law became the priority of the government of this coalition. Regarding taxes, Prime Minister declared, "It can no longer be tolerated that the treasury department interprets tax regulations arbitrarily. For many entrepreneurs, the amount of tax burden itself is not the trouble, although it is considerable, but the chaos in the regulations, ambiguities and contradictions within them" [Miller L. 2001].

Leszek Miller's government program had eleven goals, within which he declared support for small and medium enterprises. In order to encourage entrepreneurs in making bolder investments that condition economic growth, he promised them easier access to bank loans than under previous governments: "When the rules of the game are clear and the objectives are clearly defined, credit becomes cheaper and easier to access" [Miller L. 2001]. In tis respect, the priorities of entrepreneurs have not changed for a decade. Bank loans, which was to to supplement the entrepreneurs' modest capital were still difficult to access. The Prime Minister, like his predecessors, promised Poles to make efforts to improve their local roads, telecommunications and railroad infrastructure. Indeed a tool for 
economic growth. Without modern infrastructure, economic growth was increasingly threatened and Poland became a second-class country. The infrastructure mentioned by those in power is the incentive for Poland to catch up with the civilization backlog that had been accumulated over several decades of the Republic. The removal of this blockade to economic growth required investments for which the then goverment had no financial means.

Marek Belka, headed the coalition government of the centre-left, made up of the same political groups that comprised the Leszek Miller's government. The Prime Minister gave his program speech in the Sejm on May 14, 2004. Marek Belka became the first Prime Minister to lead Poland as a bonafide member of the European Union from May 1, 2004. Poland's accession to the European Union is considered, by many researchers, to be the end of the transformation stage of the Polish economy and, hence, the country's entry onto the path of a democratic state under the rule of law, with thriving a market economy.

Marek Belka announced in his exposé that the key point of his Government's program was to encourage entrepreneurs to make investments. He promised to simplify the investment process procedure. The Prime Minister justified making the investment support program one of his government's main goals by the fact that it is the first step toward creating new jobs. At the same time, Marek Belka promised to work intensively on preparing the law on freedom of economic activity. In his opinion, this law will increase "economic activity of companies and citizens" [Belka M. 2004]. The Prime Minister also raised the problem of the weakness and paresis of the economic judiciary, which was constantly present in the exposé of previous heads of government. As he stated, the improvement of this institution is "an important step to facilitate investment and business" [Belka M., 2004]. This returned to the unresolved problem of the citizens' trust in the polish justice system. One of the reasons for this was the lengthiness of court proceedings.

As a full member of the European Union Poland participated in the distribution of funds from the EU budget. In everyday language, these funds assigned to the European Union programs were spoken of as socalled EU funds. Marek Belka pointed to the need for their effective use. He wanted to achieve this goal, among other things, by announcing the preparation of a bill on public-private partnership. As the Prime Minister said, "It makes it possible to combine private and public funds for the implementation of projects co-financed by the Union" [Belka M., 2004]. In 
order for this law to become an effective tool, it was necessary to build the confidence of the partners associated with political and private institutions to face the joint investment. In Poland, due to the lack of confidence, there could potentially be difficulties in the practical application of the provisions of this law.

To sum up, both prime ministers Leszek Miller and Marek Belka, supported by the so-called centre-left groups, had no special offer for entrepreneurs. They emphasized the well-known drawback of Poland, which is the lack of trust of citizens in the state, the state towards the citizens and between the citizens themselves. They rightly considered that this situation hinders and, above all, increases the costs of running a business. They spoke in the Parliament about flaws in the Polish tax system and the institutions of justice. However, there was no ready-made recipe supported by effective government action to change this situation. Due to this state of affairs, mainly in the press, there were numerous voices of criticism from entrepreneurs. They were directed against the political camp currently in power. Henryka Bochniarz, President of the Polish Confederation of Private Employers, in her interview on December 5, 2004, stated that, "The work of an entrepreneur gives a lot of satisfaction, but still exhausting in Poland. I don't know whether anywhere in Europe it is as difficult working in the private sector as in Poland" [Mateja A. 2004: 6]. She continued by asking: "A few days ago, the law on increasing social security contributions was blocked in the Parliament. Moreover, what do I hear from government representatives? Do not let these entrepreneurs be so happy, we will come up with something else. Are we at war? After 15 years, we still do not feel that entrepreneurship is common and ours [Mateja A. 2004: 6].

The atmosphere of suspicion created by politicians, journalists and publicists regarding entrepreneurs and their work, and at the same time, the constant change of legal regulations and the lack of clear declarations from the government about coherent and predictable policies to support entrepreneurs and entrepreneurship. The lack of such policies involving the reconstruction of the tax system and the strengthening of the institutions of justice, according to Henryka Bochniarz, discouraged entrepreneurs from making investments and worsened the situation of this professional group. Henryka Bochniarz drew attention to one of the many cases of inconsistencies in the government's economic policy: "At the same time, however, the business tax was reduced to $19 \%$ and attempts were made to introduce higher social security contributions. What is state policy after all? Does it want to help the private sector, or rather to get as much out 
of it as possible? Since it is unknown, the entrepreneur, even if he has the capital, concludes that he would prefer to wait rather than invest it [Mateja A. 2004: 6].

Henryka Bochniarz drew attention to a very important problem of economic policy at the time: "How can one manage the private sector in a country that is building a free market economy without dialogue with those who create it?" [Mateja A. 2004: 6]. Polish entrepreneurs, as emphasized by Henryka Bochniarz, do not trust the state and its institutions. The rulers were unable to engage this professional group in a constructive, open and honest dialogue. According to entrepreneurs, the state always turns its back on their problems and becomes inaccessible when they are in need. Henryka Bochniarz's words are symbolic: "I travel around the country, and everywhere I meet the same conviction: in case of problems, I can only count on myself, because the state is more likely to be help the state workers than private ones" [Mateja A. 2004: 6]. An unresolved problem has arisen: how to build and strengthen formal trust, which is the basis for stimulating economic growth, in such an atmosphere. Trust is also the key to lowering the so-called transaction costs of business operations.

Elections for the fifth term were held in Poland on September 25, 2005. The mission of forming a new, right-wing government was accepted by Kazimierz Marcinkiewicz. He built a government coalition composed of the following political parties: Prawo i Sprawiedliwość, Samoobrona RP, Liga Polskich Rodzin (Law and Justice, Polish Self-Defense, League of Polish Families). The Prime Minister gave a program speech in the Parliament on November 10, 2005. In his exposé, Kazimierz Marcinkiewicz emphasized the main goal of his government, which was to "fix the state" [Marcinkiewicz K. 2005]. Referring to the past, mainly the government and the program of Jan Olszewski, Kazimierz Marcinkiewicz spoke about the state's corruption" in a way similar to a mechanism that does not properly perform the functions for which it was created. He also spoke of moral corruption" [Marcinkiewicz K. 2005]. As he emphasized, in such a situation "Poles cannot respect or put their trust in the institutions of such a state" [Marcinkiewicz K. 2005]. Kazimierz Marcinkiewicz pointed out, assessing the state of Poland, the need to break with the past and announced the program of building the 4th Republic of Poland [Marcinkiewicz K. 2005]. This announcement was connected with the program of strengthening political power and greater centralization. In the Prime Minister's opinion, the state as an institution was to be strong thanks to the adopted values. 
On this foundation, he planned to carry out a moral renewal of society and to rebuild the institution.

Inhis exposé, Kazimierz Marcinkiewicz madean offer for entrepreneurs. The Prime Minister proposed "facilitation and elimination of bureaucratic barriers while starting a business, as well as during its running". He announced that the government would simplify the economic law, seek to limit the required licenses and permits, and speed up the processing of cases in commercial courts [Marcinkiewicz K. 2005]. The above proposals, however, did not differ significantly from those made by his predecessors.

Jarosław Kaczyński replaced Kazimierz Marcinkiewicz as Prime Minister, creating a coalition government, which consisted of the same political groups that formed the previous one. The new Prime Minister gave his program speech in the Sejm on July 19, 2006. During his long program speech, the Prime Minister did not offer much to entrepreneurs. He pointed out that "We have a chance for a new wave in Polish economic life. We have a chance for a new wave of Polish capitalism. Perhaps the one resembling the previous one, however, better and stronger than that which appeared at the turn of the 1980s and 1990s and brought the first economic successes in the mid-1990s. I repeat we have such a chance. We only have to strive together to use our resources and assets" [Kaczyński J. 2006]. Jarosław Kaczyński pointed out that by "resources and assets" he meant the intellectual resources of the enlightened Polish society post 1989. The second resource, according to the Prime Minister, was an institutional one. This resource, in his opinion, required a thorough repair. Jarosław Kaczyński criticized the excessive bureaucracy of the Polish economy and its overregulation as a result. This factor, in his opinion, discouraged entrepreneurs from expanding their businesses. Another pathology, according to the Prime Minister that poisons the Polish economic life was supposed to be corruption, especially onerous when it appeares in state institutions [Kaczyński J. 2006]. The Prime Minister also referred to the privatization of state assets (changes of ownership). He said that there were many cases of unjustified privatization. The situation needed to be cured and the pathologies expunged. Jarosław Kaczyński emphasized that he valued the intellectual resources of the Polish society and saw the remedy for their release as the realization of the political project of the Fourth Republic of Poland [Kaczyński J. 2006].

The exposé of two Prime ministers Kazimierz Marcinkiewicz and Jarosław Kaczyński, politicians who built a coalition government based 
on right-wing parties, covered two spaces. The first was an evaluation of the past and was negative in its meaning. The past is, according to these speakers, a mistake and a drift of society towards moral corruption. The second space is the moral renewal of the nation, the creation of a new project, called the program of the Fourth Republic. A strong state that will build new institutions and lead to a sustainable economic growth. Kazimierz Marcinkiewicz and Jarosław Kaczyński evaluated the achievements of the years following 1989 from the perspective of the moral defeat of the nation and state. They did not look at the information coming from the economy.

Fast-track parliamentary elections following the interruption of the fifth term of the Sejm and Senate were held on October 21, 2007. Donald Tusk became Prime Minister of the new coalition, consisting of two political parties, Platforma Obywatelska and Polskie Stronnictwo Ludowe (the Civic Platform and the Polish People's Party). Asking the Sejm of the sixth term to cast a vote of confidence for himself and the government, the Prime minister gave an exposé on November 23, 2007. As he stated, in opposition to his predecessor, "Poles do not need and do not want power whose ambition is to change them. Because Poles do not need to be changed. Together we must change the living and working conditions of Poles for the better" [Tusk D. 2007].

The Prime Minister stated, "In a market economy based on voluntary cooperation between citizens, trust is paramount. First and foremost, this means the conviction that the benefits, which everyone derives from their economic activity, hired work or for running a company will be proportional to the real effects of their activity. This means the right to a fair wage, but also to a fair profit" [Tusk D. 2007]. The profit in this statement became, according to Adam Smith's views, a reward to the entrepreneur for the risk taken. The Prime Minister proclaimed, “... we will simultaneously work to strengthen the respect for those whose entrepreneurship and professionalism create jobs for others. These people constitute a source of income thanks to which the state can perform its constitutional functions better" [Tusk D. 2007]. In Donald Tusk's program speech, entrepreneurs were recognized as those whose work contributes to the nation's wealth. The Prime Minister pointed out that entrepreneurs could not be suspected for perpetually plotting and conspiring to hide their income from state institutions. Donald Tusk announced a change in the economic policy regarding entrepreneurs. He promised a constant support for entrepreneurship. He declared a need to change the law so as 
to make it easier, not more difficult for entrepreneurs to do business. He announced a reduction in taxes. The Prime Minister stated with conviction that "...free people produce more and more goods". He explained, "This is the essence of democratic capitalism, this is the essence of the policy we want to propose today to Poles - liberal economic policy and social solidarity policy" [Tusk D. 2007]. Donald Tusk emphasized that without the economic freedom that citizens should enjoy, the development of the economy is dying out while its growth is slowed down. Social solidarity is required for economic development to serve the populace. The Prime Minister, addressing entrepreneurs, said: "In order to be able to spend more, whether on infrastructure or on increasing salaries in the public sphere, we must give a chance to those who do not expect money from the state, but expect more freedom, more independence, more confidence in their entrepreneurship" [Tusk D. 2007]. The Prime Minister declared "Maximum freedom and trust towards those who do not need help, who are able to build their own and others' economic successes". Donald Tusk, in the context of supporting entrepreneurs and entrepreneurial attitudes declared, "The right to property is, aside from the right to life and freedom, one of the fundamental human rights and constitutes the foundation of legal, economic and social order. Ownership is a condition for civil liberty and sustainability" [Tusk D. 2007].

Donald Tusk, who came from the circle of the so-called Liberals of Gdańsk, adopted the principle of freedom of management as a message of economic policy. With his speech, he wanted to arouse the enthusiasm of entrepreneurs, by declaring to them the inviolability of the right to own property. He emphasized, after Adam Smith, that the work of entrepreneurs is a source of income for the state and hence the nation's wealth. Donald Tusk stated a need to strengthen economic and political institutions. The beginning of this path was to be marked by trust, which he wanted to rebuild in mutual dialogue between entrepreneurs and institutions representing the state. At the same time, he hoped that the mechanisms for the functioning of inclusive economic institutions, which support economically active people will be strengthened [Acemoglu D, Robinson J.A. 2014: 90-1].

In April 2008, Prof. Leszek Balcerowicz, the main director of the transformation of the Polish economy after 1989, published an article in the opinion-forming periodical "Gazeta Wyborcza" under the significant title "Foolish institutions! [Balcerowicz L., 2008: 33]. Leszek Balcerowicz drew the readers' attention to the fact that "The living conditions of 
a contemporary society depends, mainly, on the state, its shape, what it does. (...) It is very often repeated without reflection that, "if the state does not do something, nobody will". (...)Statist fans of collectives neither appreciate the costs of state intervention nor the possibility of people acting in non-state structures: companies (market) and NGOs (civil society)" [Balcerowicz L. 2008].

By the decision of the voters on October 9, 2011, the ruling coalition of the PO-PSL (the Civic Platform and the Polish People's Party) was given the mandate to hold power again. Donald Tusk became Prime Minister for a second term. In his exposé to the Sejm for the seventh term, on November 18, 2011, he devoted little attention to entrepreneurs or the support for entrepreneurial resource, in contrast to the exposé he delivered four years earlier. The Prime Minister would rather emphasized the good economic results achieved by Poland in the previous term under his government, pointing out that these good economic results were primarily thanks to all the Poles, their effort, patience and determination [Tusk D. 2011].

Donald Tusk presented a richer offer to entrepreneurs in the so-called second exposé, which he gave in the Sejm on 12 October 2012. In this speech, he pointed out primarily the treasury and taxes, as areas in need of improvement in order to increase the level of economic growth. He announced facilitations concerning VAT and announced the introduction of a change in the way of calculating this tax [Tusk D. 2012]. This was to be an offer addressed primarily to small companies. However, no specifics were made in this respect. The Prime Minister raised the problem of streamlining the work of courts in economic matters (organization of the economic court center), declared the preparation of a new bankruptcy law and a new construction code. He proposed to make employment more flexible by extending the settlement period of working time to 12 months and introducing the so-called mobile working time [Tusk D. 2012]. In this way, he wanted to support entrepreneurs and stimulate the labor market.

Ewa Kopacz, Prime Minister of the Polish government of the coalition of the PO - PSL (the Civic Platform and the Polish People's Party), gave an exposé on October 1, 2014. In her speech, the Prime Minister devoted a lot of time to discussing the problems of entrepreneurs and support for entrepreneurship on the part of those in power. Ewa Kopacz said, "Poles are still hungry for success" [Kopacz E. 2014]. Evaluating social expectations from this perspective, Ewa Kopacz pointed out that it is absurd for political institutions to assume that entrepreneurs always try to break or bypass applicable laws when starting a business. Following 
this conviction, the Prime Minister announced the implementation of the "99\% rule". It was to be based on the principle "that all our laws in the area of economic freedom are created with those 99\% honest in mind, not the 1\% smart in mind" [Kopacz E. 2014]. Ewa Kopacz, referring to the tax policy, which directly affected entrepreneurs, announced changes that "the tax system does not punish Poles for their resourcefulness, diligence or effectiveness" [Kopacz E. 2014]. The Prime Minister declared broad support for micro-entrepreneurs. She said that they will be able to count on the help of a tax assistant and that the tax system will be built in such a way as to be consistent. By this notion, she understood the principle that the interpretation of tax law for employers will be uniform across the country. The introduced "de minimis" program, which included loan guarantees for micro and small businesses, extended government assistance to support exports [Kopacz E. 2014]. Ewa Kopacz's announcements were in line with the economic policy drawn in 2007. In this respect, the priorities have not changed.

The election of the parliament for the eighth term took place on 25th October 2015. By the decision of the voters, the mandate to form a government was given to a coalition of Zjednoczona Prawica (the United Right), comprising of the following political parties: Prawo i Sprawiedliwość, Solidarna Polska and Polska Razem (Law and Justice, Solidarity Poland and Poland Together). Beata Szydło became Prime Minister of the government. In her exposé delivered on November 18, 2015, the Prime Minister spoke of the need to pull Poland out of the trap of average development. This concept appeared in public discourse. Exiting the trap of an average development was to be the way to a new opening in economic policy of the United Right-wing government. Beata Szydło said in her expose that the first reserve that must be used for active economic policy to pull Poland out of the trap of an average development is "the entrepreneurship of Poles who are already operating in the economy, who run their own businesses, as well as those who can, at least potentially, do so" [Szydlo B., 2015]. The Prime Minister said, "Poland needs the entrepreneurship of young, well-educated Poles. Continuing this theme, Beata Szydło stated that Polish entrepreneurs are afflicted with a lack of capital, often caused by a lack of creditworthiness. Entrepreneurs struggle with bureaucratic barriers, "disturbances of pure market rules" [Szydlo B. 2015].

Beata Szydło, after presenting a diagnosis of the state of the economy and state institutions, discussed the remedy she intends to apply. She 
announced tax cut for small and medium-sized enterprises and removal of bureaucratic obstacles in the running of a company. She expected that young entrepreneurs would introduce into the economy an invigorative blast of innovations and new technologies that will help to build a knowledge-based economy in Poland, and thus escape the trap of average development. Beata Szydło said, "We have a program that will make small companies medium sized, the medium sized large ones and large companies will be able to compete on the global market. This program is, among others, a double investment write-off for entrepreneurs who will reinvest the money they earn in the development of their companies" [Szydlo B. 2015]. The support for such companies was also to come from a new institution established by the Prime Minister, namely, the National Forum of Entrepreneurs. The Prime Minister also announced the creation of scientific and research facilities for small and medium-sized enterprises [Szydlo B. 2015].

Beata Szydło appealed to entrepreneurs to increase the level of investment in Poland. In her opinion, this goal can be achieved through the effective use of funds from European Union programs. The second source of capital are the banks from which the Prime Minister expected to launch "low-interest loans for development purposes". She said that these instruments would ensure the elimination of the barriers for many entrepreneurs to enter the market and lay the foundations for the development of small and medium-sized companies [Szydlo B. 2015]. The Prime Minister pointed out that the next resource that needs to be launched is the savings on the accounts of enterprises. In her opinion, "amortization of investments within a year, or even double amortization in the case of innovative investments, can help get them started" [Szydlo B. 2015]. The government planned to strengthen the enterprise Polskie Inwestycje Rozwojowe (Polish Development Investments), which was named "Polish Investments" and "Consolidation of the Bank of National Economy". The investment was also to be stimulated by large state-owned enterprises, which were to create a so-called investment fund. This widely discussed economic program, as an offer for entrepreneurs, establishes greater activity of state institutions in stimulating the market economy. There was a tendency to move away from the minimum state to an active state in the economy.

Mateusz Morawiecki, who replaced Beata Szydło as Prime Minister, presented the program of the government of the same coalition as his predecessor in an exposé before the Sejm on 12 December 2017. Mateusz 
Morawiecki, in the first part of the program speech, announced clearly, "The state is returning to the game for good. The enterprising entrepreneurs are now joined by an enterprising state. The state has laid the foundations for success in the likes of the American Silicon Valley or Israeli innovation, or Korean or German industry. A golden mean must be found between a minimum state that abandons its citizens, as was often the case in our recent past, and a heavily bureaucratic state. We want neither" [Morawiecki M. 2017].

The Prime Minister, presenting the objectives of the government's economic policy, proposed a "great modernization of Poland" and the country's active participation in the global technological revolution. In his opinion, this revolution comes down to "a new deal in world economy". He declared, "We have the largest government support program for young technology companies in this part of Europe." Mateusz Morawiecki emphasized that this program will be implemented by the state, through the provision of support to entrepreneurs: "We therefore need the state with a strong identity to break away from the role of the periphery in modern capitalism. Thus, one of the main ideas for the development plan is to promote Polish companies as global champions" [Morawiecki M. 2017]. The Prime Minister expected a greater involvement of young people, who, in his opinion, are the guarantors of innovation and modernization. Mateusz Morawiecki resigned from using the term "average economic growth trap". He presented a vision of an active state, which supports the changes in the economy as defined by the Fourth Industrial Revolution [Schwab K. 2018: 18-9]. He proposed to use the intellectual resources of the Polish society to include Poland in the global trend of new technologies.

Mateusz Morawiecki announced the necessity of a further sealing of the tax system in Poland. Realizing that this is a program whose negative consequences for companies are feared by many entrepreneurs, he spoke to them in a calming tone: "For the small and medium-sized entrepreneurs I have an important message: all honest entrepreneurs can expect the legal environment to be taken care of and equal competition rules at the same time" [Morawiecki M. 2017]. He announced the preparation of the so-called "Constitution of Business", a package of legal acts simplifying business activity. He spoke, like his predecessors, about the need to streamline the courts so that entrepreneurs could pursue their claims there within a reasonable time.

Elections to the ninth term of the Sejm took place on October 13, 2019. The Council of Ministers, being a coalition government of Zjednoczona 
Prawica (the United Right), was headed by Mateusz Morawiecki for the second time. In his program speech, which was delivered by the Prime Minister himself at the session of the Sejm on November 19, 2019, he confirmed that, invariably, the state's great involvement in the economy will be the priority of the government's economic policy. An active state is to be a tool for stimulating economic growth. The Prime Minister was convinced that the state is restoring normality on the market. He pointed out, referring to the exposé of 12 December 2017, that in order to enter the global network of modern economies, Poland should make use of the talent and knowledge of its citizens, innovations, regulations, effectiveness and efficiency [Morawiecki M. 2019]. The vision of Poland as a co-creator of the fourth industrial revolution has remained an important element in the construction of this government's economic program.

Mateusz Morawiecki presented the entrepreneurs with an offer of respect for economic freedom by state institutions. He proposed to this group to begin work on building a "deregulation and freedom package for citizens and business". He did not indicate the details of this document however. The Prime Minister said, "Entrepreneurship is the heart of any modern economy," and "The state has a duty to support entrepreneurs, create conditions for their development, and provide them with a predictable law that allows them to plan their investments as well as a tax system that motivates development" [Morawiecki M. 2019]. In the project of economic policy, Mateusz Morawiecki declared that he would support "Polish companies, because this is an absolute norm and normality". In tax matters, he once again declared to the entrepreneurs his willingness to reduce taxes, simplify the tax law, and limit fiscal controls. He promised to introduce investment reliefs for micro-entrepreneurs and "the so-called Estonian CIT for micro and small companies, i.e., the postponement of tax collection until the moment of profit distribution by the company. It supports the reinvestment of profits and facilitates own financing for small companies that are in great need of a capital injection" [Morawiecki M. 2019]. The economic program of the government also included a slogan of repolonization. The Prime Minister explained this concept as follows: „because the more Polish companies, the more freedom and prosperity, the more normality" [Morawiecki M. 2019]. 


\section{CONCLUSIONS}

Following the programme announcements of the government's economic policy towards entrepreneurs, included in the exposé of the Prime Ministers from Tadeusz Mazowiecki to Mateusz Morawiecki, there is a clear evolution in the politicians' views on the subject. Tadeusz Mazowiecki spoke about the withdrawal of the state from the economy, about giving this capacity to the citizens. The ideal solution was a'minimum state', creating conditions for citizens to get richer. Successive heads of the Polish government maintained the principle of a minimum state. The assessment of the privatization policy of state enterprises was gradually changing. The prime ministers emphasized the need to privatize many of them, but they softened the tone of their statements, also talking about the need to keep those enterprises that are able to compete as national companies. A clear change in the economic policy of the government was evident with the government of Beata Szydło and Mateusz Morawiecki. They proposed to move away from the idea of a minimum state economy. They expressed the will that the state should not only regulate economic processes, but also should actively participate in them and be the initiator of the required change.

Another interesting element is the one included in the program speeches of the heads of government. In the exposé, political interest, often coalition interest, always prevailed over pragmatism. Some of the heads of government talk cautiously about entrepreneurs and spoke with relative ease. There was no offer for this professional group, apart from promises to improve the work of the judiciary and make changes in tax laws. The prime ministers, as Henryka Bochniarz remarked, did not like to meet with entrepreneurs, because it looked rather uncomfortable. It was easier for them to talk about the privatization of state-owned enterprises, about social support within the framework of the extended social policy offer. In the program speeches, the word "entrepreneur" and "entrepreneurship" was spoken a few times. The government's policy towards entrepreneurs changed radically with the program speech of Prime Minister Donald Tusk. He spoke openly about the freedom of people to run their businesses and the trust they have in entrepreneurs. Subsequent prime ministers maintained this tone of kindness towards entrepreneurs. Mateusz Morawiecki presented a wide-range of offers to this group. He divided the entrepreneurs into those who are honest and 
those who should be afraid of the inevitable penalties for treasury matting. He emphasized that the state will take care of native entrepreneurs, as this is the natural attitude of every government. Mateusz Morawiecki, emphasizing the need for an active state in the economy, announced support for domestic entrepreneurs who will place Poland among the leaders of the new revolution in the global economy.

\section{BIBLIOGRAPHY}

\section{Literature}

Acemoglu D., Robinson J.A. (2014), Dlaczego narody przegrywają. Źródła władzy, pomyślności i ubóstwa, Wydawnictwo Zysk, Warszawa.

Balcerowicz L. (2008), Instytucje głupcze!, Gazeta Wyborcza, 99(5709), 33-34.

Bielecki J.K. (1991), Exposé Prezesa Rady Ministrów Jana Krzysztofa Bieleckiego, [in:] Sprawozdania Stenograficzne z 48 posiedzenia Sejmu RP w dniach 4 i 5 stycznia 1991 r., Sejm Rzeczpospolitej Polskiej, Kadencja X, Warszawa.

Fukuyama F. (1989), The End of History?, The National Interest, 16, 3-18.

Exposé Prezesów Rady Ministrów 1989-2019, (2020), Marszałek-Kawa J., Siemiątkowski P. (eds.), Wydawnictwo Adam Marszałek, Torun.

Kurczewski J. (2006), Rzecz solidarna i jej wrogowie, Tygodnik Powszechny, 5, 3-5.

Morawski W. (1998), Zmiana instytucjonalna. Społeczeństwo. Gospodarka, Polityka, Wydawnictwo Naukowe PWN, Warszawa.

Oleksy J. (1995), Exposé Prezesa Rady Ministrów, Przegląd Rządowy, 3-4, 45-46.

Rocznik statystyczny, (1991), GUS, Warszawa.

Schwab K. (2018), Czwarta rewolucja przemystowa, Wydawnictwo Studio Emka, Warszawa.

Mateja A. (2004), Szkodliwy klimat. Z Henryka Bochniarz prezydent Polskiej Konfederacji Pracodawców Prywatnych rozmawia Anna Mateja, Tygodnik Powszechny, 49, 6.

Wilczyński W. (2001), Wstydliwa choroba, Wprost, 13, s. 35.

\section{Studies in electronic format}

Belka M. (2004), Przedstawienie przez prezesa Rady Ministrów programu dziatania Rady Ministrów z wnioskiem o udzielenie jej wotum zaufania, IV kadencja, 75 posiedzenie, 4 dzień (14.05.2004), http://orka2.sejm.gov.pl/Debata4.nsf/118b9e577f3fceeac125746d0030d Ofa/51bd2f28799939f7c125747800463cdb?OpenDocument, accessed 17.12.2020.

Buzek J. (1997), Przedstawiony przez prezesa Rady Ministrów program działania Rady Ministrów wraz $z$ wnioskiem o udzielenie jej wotum zaufania, III kadencja, 2 posiedzenie, 1 dzień (10.11.1997), http:// orka2.sejm.gov.pl/Debata3.nsf/118b9e577f3fceeac125746d0030d Ofa/a50f5bf4c1a99521c1257490004b6c29?OpenDocument, accessed 17.12.2020.

Cimoszewicz W. (1996), Przedstawiony przez prezesa Rady Ministrów program działania rządu wraz z wnioskiem o udzielenie wotum zaufania, II kadencja, 73 posiedzenie, 1 dzień, http:// orka2.sejm.gov.pl/Debata2.nsf/118b9e577f3fceeac125746d0030d0fa/acf6f103 d150e9ebc12574ef0039e0db?OpenDocument, accessed 17.12.2020.

Kaczyński J. (2006), Przedstawienie przez Prezesa Rady Ministrów programu działania Rady Ministrów z wnioskiem o udzielenie jej wotum zaufania, V kadencja, 22 posiedzenie, 
2 dzień , http:/ / orka2.sejm.gov.pl/ Debata5.nsf/7105daf5973e96b5c125745f00379391/ 9691935764d5b043c125746500448af1?OpenDocument, accessed 17.12.2020.

Kopacz E. (2014), Program działania Rady Ministrów z wnioskiem o udzielenie jej wotum zaufania, LXXII posiedzenie, 1 dzień (1.10.2014), http:/ /orka2.sejm.gov.pl/StenoInter7. nsf/0/D4E8C869CD930B1DC1257D64007A0F97/\%24File/76_ksiazka_bis.pdf, accessed 17.12.2020.

Marcinkiewicz K. (2005), Przedstawienie przez prezesa Rady Ministrów programu działania Rady Ministrów z wnioskiem o udzielenie jej wotum zaufania, V kadencja, 2 posiedzenie, 2 dzień (10.11.2005), http://orka2.sejm.gov.pl/Debata5.nsf/7105daf5973e96b5c125745f00379 391/078c9da5cb858bb5c125746400474a0f?OpenDocument, accessed 17.12.2020.

Mazowiecki T. (1989a), Tadeusz Mazowiecki, Wstępne exposé Prezesa Rady Ministrów, http:/ / publica.pl/teksty/chce-byc-premierem-rzadu-wszystkich-polakow-50729.html, accessed 1.06.2016.

Mazowiecki T. (1989b), Drugie exposé premiera Tadeusza Mazowieckiego w Parlamencie, http:/ / orka2.sejm.gov.pl/StenogramyX.nsf/0/259278CD28DE3BBDC1257D20002C C6FD/\$file/006_000006771.pdf, accessed: 17.12.2020.

Miller L. (2001), Przedstawienie przez prezesa Rady Ministrów programu działania Rady Ministrów z wnioskiem o udzielenie jej wotum zaufania, IV kadencja, 2 posiedzenie, 1 dzień (25.10.2001), http:// orka2.sejm.gov.pl/Debata4.nsf/118b9e577f3fceeac125746d0030d Ofa/953ba2023e92718dc12574710030b82d?OpenDocument, accessed 17.12.2020.

Morawiecki M. (2017), Exposé premiera Mateusza Morawieckiego - stenogram, https:/ /www. premier.gov.pl/expose-premiera-mateusza-morawieckiego-stenogram.html, accessed 10.08.2020.

Morawiecki M. (2019), Stenogram exposé Mateusza Morawieckiego 2019, https://www. gov.pl/web/premier/stenogram-expos-mateusza-morawieckiego-2019, accessed 16.08.2020.

Olszewski J. (1991), EOświadczenie prezesa Rady Ministrów w sprawie proponowanego składu i programu prac rządu, I kadencja, 3 posiedzenie, 1 dzień (21.12.1991) http:/ / orka2.sejm. gov.pl/Debata1.nsf/118b9e577f3fceeac125746d0030d0fa/23559e9ea6c0d69ac1257505 004555f4?OpenDocument, accessed 17.12.2020.

Pawlak W. (1993), Przedstawiony przez prezesa Rady Ministrów program działania rządu wraz z wnioskiem o udzielenie wotum zaufania, II kadencja, 2 posiedzenie, 1 dzień (8.11.1993), http:/ / orka2.sejm.gov.pl/Debata2.nsf/118b9e577f3fceeac125746d0030d0f a/cea5d9e566ae02d1c12574e4003f51a8?OpenDocument, accessed 17.12.2020.

Suchocka H. (1992a), Oświadczenie prezesa Rady Ministrów w sprawie proponowanego składu i programu prac rzadu, I kadencja, 20 posiedzenie, 1 dzień (10.07.1992), http:/ / orka2. sejm.gov.pl/Debata1.nsf/118b9e577f3fceeac125746d0030d0fa/42081e9872e82946c125 750c00439ec8?OpenDocument, accessed 17.12.2020.

Suchocka H. (1992b), Programowe zadania i zasady dziatania rzadu. Wystapienie premier Hanny Suchockiej w Sejmie 9 października 1992 http:/ / orka2.sejm.gov.pl/Debata1.nsf/118b9e 577f3fceeac125746d0030d0fa/420bcbacb876daeec125750c0045b840?OpenDocument, accessed 17.12.2020.

Szydło B. (2015), Exposé Prezesa Rady Ministrów Beaty Szydło, https://www.premier.gov. $\mathrm{pl}$ /expose-premier-beaty-szydlo-stenogram.html, accessed 10.08.2020.

Tusk D. (2007), Przedstawienie przez prezesa Rady Ministrów programu działania Rady Ministrów z wnioskiem o udzielenie jej wotum zaufania, 6 kadencja, 2 posiedzenie, 1 dzień (23.11.2007), http:/ / orka2.sejm.gov.pl/Debata6.nsf/7075e4662b58d9b1c125737f0039d 549/c2f0913296a12fedc12573ad0041f851?OpenDocument, accessed 17.12.2020. 
Tusk D. (2011), Exposé Prezesa Rady Ministrów Donalda Tuska, https://www.premier.gov. $\mathrm{pl} /$ realizacja-planow/expose-premiera-donalda-tuska-stenogram.html, accessed 17.12.2020.

Tusk D. (2012), Drugie exposé premiera Donalda Tuska - stenogram, https:/ /www.premier. gov.pl/realizacja-planow/drugie-expose-premiera-donalda-tuska-stenogram.html, accessed 17.12.2020.

Sławomir Kamosiński, Ph. D., is a professor at Kazimierz Wielki University in Bydgoszcz, at the Institute of Law and Economics. Scientific interests: economic history of the twentieth century, with particular emphasis on the history of industry and enterprises; brands and their historical development; privatization and restructuring of enterprises; entrepreneurs and entrepreneurship in Poland after 1989. 